\title{
How Key Psychological Theories Can Enrich Our Understanding of Our Ancestors and Help Improve Mental Health for Present and Future Generations: A Family Historian's Perspective
}

\author{
Helen Parker-Drabble
}

Citation: Parker-Drabble, Helen. 2022. How Key Psychological Theories Can Enrich Our Understanding of Our Ancestors and Help Improve Mental Health for Present and Future Generations: A Family Historian's Perspective. Genealogy 6: 4. https://doi.org/ 10.3390/genealogy6010004

Received: 19 October 2021

Accepted: 18 December 2021

Published: 31 December 2021

Publisher's Note: MDPI stays neutral with regard to jurisdictional claims in published maps and institutional affiliations.

Copyright: (C) 2021 by the author. Licensee MDPI, Basel, Switzerland. This article is an open access article distributed under the terms and conditions of the Creative Commons Attribution (CC BY) license (https:// creativecommons.org/licenses/by/ $4.0 /)$.
Independent Researcher, London W1A 6US, UK; helen@helenparkerdrabble.com or h_parker_drabble@hotmail.com; Tel.: +44-7871-203-644

\begin{abstract}
Family historians could increase their understanding of their ancestors and themselves and improve the mental health of living and future generations if they consider the psychological history of their forebears. Genealogists could then begin to recognize their family's unique psychological inheritance that can appear as a result of trauma, depression, or addiction. The author explores three generations of a Parker family branch from Huntingdon/Norfolk, England, to show family historians how such considerations can shed light on their family's psychological legacy. The author does this by introducing us to her great-grandmother Ann grandfather Walter, and mother Doreen through the lens of attachment theory, and their adverse childhood experiences (ACEs) such as poverty, bereavement, and addiction. Attachment matters because it affects not only how safe we feel, our ability to regulate our emotions and stress, our adaptability, resilience, and lifelong mental and physical health, but attachment style can also be passed on. In addition, this paper utilizes attachment theory to speculate on the likely attachment styles for the three generations of the Parker family and looks at the possible parenting behavior in the first two, the effect of alcoholism and the intergenerational impact of trauma and depression.
\end{abstract}

Keywords: genealogy; family history; attachment; depression; trauma; prolonged grief disorder; adverse childhood experiences; alcoholic; alcohol use disorder; bereavement

\section{Introduction}

In 2013, I discovered that my grandfather Walter Parker's home in The Tank Yard, Thorney, Cambridgeshire, England, had become a museum. The day I visited, a volunteer steward told me about a cousin named Mary (born in 1918) who he thought would be delighted to meet me. Mary welcomed me as family and an important bridge to her past. Nearing the end of her life, she had lost most of her sight and was, as she said, "sliding toward death" in a "comfortable" nursing home. She had outlived her peers, husband, and only child, while her remaining sister had Alzheimer's disease. In the 1920s, Mary's uncle Walter taught her to ice skate, and as she told me about that winter, her face lit up. In her remaining years, Mary brought alive the "model" Victorian village of her childhood, built, and still owned by the Dukes of Bedford. As I absorbed the stories, I saw with delight that Mary found unexpected meaning and new purpose in relating the joys, domestic details, and tragedies woven into our family's daily life.

Later, I was not surprised to learn that sharing family history can boost one's mood and create bonds of common interest (Moore et al. 2020); but genealogy can do much more. According to Evans (2021, p. 101), "family history reconstructs memories about family lives in the past and in that process reveals the ... secret keeping, emotional familial management, and its impact on people in the past and present". I propose that any psychological insight genealogists uncover can give individuals new opportunities to thrive 
and pass on a healthier psychological legacy. Indeed, historian Emma Shaw reports in her article Who we are and why we do it that the goal of some family historians is "to uncover any inheritable ... traits and/or conditions that may impact negatively on those in the present. For these respondents, family history research was a tool in which certain medical traits could be identified, traced, and perhaps eradicated" (Shaw 2020, p. 119). In How do Family Historians Work with Memory?, public historian Tanya Evans quotes author Betty O'Neil, "family history is a microhistory, an individual and family experience of a particular time in history and geography that reflects many of the larger national, transactional and global themes" (Evans 2021, p. 98). For me, a motif around mental health, particularly depression, resonated most strongly. It first emerged from conversations with my cousin Mary, who described relatives who struggled with their psychological well-being and reminded me of the depressive episodes my mom and I suffered. I submit that family history knowledge can allow us to recognize and challenge maladaptive behavior, makes available important medical information, and opens the possibility to reverse a negative or toxic psychological inheritance and bring about positive change, whether self-directed or guided by mental health professionals, thereby allowing us to leave a more positive psychological legacy.

My mother, Doreen (born 1938), rationalized the distant relationship she had with her father in part due to his age of 51 when she was born. She also told me how Walter's social and emotional development had been interrupted by decades spent in an isolated homestead on the Canadian Prairies, leaving him firmly trapped in the Victorian mind-set of his youth. However, in this paper, I consider the lives of three generations: Ann, Walter, and Ann Parker through the lens of attachment theory and the impact his mother's poverty, bereavement, depression, and alcoholism had on him and his daughter, Doreen. This is important because attachment has lifelong consequences and attachment styles can be passed down the generations. I believe such investigations can help family historians bring toxic secrets and patterns of belief and behavior into the open, so that genealogists can weave them into their own narrative in the hope that this process lessens or brings to an end intergenerational trauma (Evans 2021, p. 100).

\section{Results the Method Employed}

The method employed was to collate births, deaths, causes of death, census records, reports from the Huntingdon Archive, interviews of people who knew Ann, Walter and Doreen and the author's own memories. The experience of each is related in the narrative and summarized in Table 1 below. I consider adverse childhood experience (ACE) studies that find links between the number of adversities and adult psychological health (including alcoholism) and physical health outcomes (Felitti 2002) as well as the impacts of traumatic loss, bereavement, depression, and alcoholism. I set these against the historical backdrop of migration, the Great Depression, and the Second World War by linking them to corroborating information - for example around living alone (Walter), being unusually self-reliant (Walter and teenage Doreen) and a brief description of Doreen's mother, Hilda. This paper utilizes attachment theory to speculate on likely attachment styles and parenting behavior. 
Table 1. Summary of three generations of the Parker family.

\begin{tabular}{|c|c|c|c|}
\hline $\begin{array}{l}\text { Name; } \\
\text { Birth; Occupation; } \\
\text { Marriage; Death; } \\
\text { Cause of Death }\end{array}$ & Places Lived & $\begin{array}{l}\text { Proposed Attachment Style. } \\
\text { Adverse Childhood Experiences (ACEs) } \\
\text { Loss/Trauma }\end{array}$ & Mental Health \\
\hline $\begin{array}{l}\text { First generation (4.1) } \\
\text { Name } \\
\text { Ann Parker née Bates } \\
\text { Birth } \\
1856 \\
\text { Alconbury-Cum-Weston, } \\
\text { Huntingdonshire, England. } \\
\text { Occupation } \\
\text { Domestic servant. } \\
\text { Marriage } \\
1880 \\
\text { St Peter's, Upwell, Norfolk. } \\
\text { Death } \\
1938 \text { Thorney, } \\
\text { Cambridgeshire. } \\
\text { Cause of Death } \\
\text { Fibroid degeneration of the heart }\end{array}$ & $\begin{array}{l}\text { Alconbury-Cum-Weston, } \\
\text { Huntingdonshire, England. } \\
\text { Upwell, Norfolk; Thorney, } \\
\text { Cambridgeshire. }\end{array}$ & $\begin{array}{l}\text { Avoidant attachment style. } \\
\text { Childhood lived in poverty. } \\
\text { Three siblings died before Ann's birth, (from } \\
\text { meningitis, unknown cause, and fever). } \\
\text { Age 2, brother Alfred died at } 8 \text { months; } \\
\text { Tabes Mesenterica. } \\
\text { Age 4, mother died; phthisis (consumption). } \\
\text { Age } 6 \text { father remarries. } \\
\text { Before age 7, sister Mary moves away. } \\
\text { Age 7, sister Mary marries. } \\
\text { 1873-1874, father and stepmother and } 2 \text { half } \\
\text { siblings moved in and out of the workhouse. } \\
\text { 1875, father dies in the workhouse. } \\
\text { 1876, stepmother dies in workhouse. } \\
\text { 1883, firstborn Lily Ann dies at } 18 \text { months } \\
\text { old, TB meningitis. }\end{array}$ & Alcoholic; depression \\
\hline $\begin{array}{l}\text { Second generation (4.2) } \\
\text { Name } \\
\text { Walter Parker } \\
\text { Occupations Agricultural laborer; } \\
\text { apprenticeship carpenter and joiner; } \\
\text { homesteader; joiner for the London, } \\
\text { Midland and Scottish Railway, Sheffield; } \\
\text { after retirement, worked for a garage } \\
\text { until aged } 89 \text { years. } \\
\text { Birth } \\
\text { 1885, Upwell, Norfolk. } \\
\text { Marriage } \\
\text { 1936, St Mary's, Sheffield, now the } \\
\text { cathedral. } \\
\text { Death } \\
\text { 1975, Arkley, Hertfordshire. } \\
\text { Cause of Death } \\
\text { Cardiac arrest; congested heart failure. }\end{array}$ & $\begin{array}{l}\text { Upwell, Norfolk. } \\
\text { Thorney, Cambridgeshire. } \\
\text { Homestead Nw-22-24-7 } \\
\text { West, Canada; Ashern, } \\
\text { Manitoba, Canada. } \\
\text { Edmund Road, Sheffield. } \\
\text { Arkley, Barnet, } \\
\text { Hertfordshire. }\end{array}$ & $\begin{array}{l}\text { Dismissing-avoidant attachment style. } \\
\text { 1883, death of sister before his birth. } \\
\text { Alcoholic mother. } \\
\text { 1909-1931, isolation on the Canadian } \\
\text { Prairies. } \\
\text { 1939-1945, heavy duty squad WW2. } \\
\text { 1940, Sheffield Blitz. }\end{array}$ & $\begin{array}{l}\text { Depression, lifelong } \\
\text { smoker. }\end{array}$ \\
\hline $\begin{array}{l}\text { Third generation (4.3) } \\
\text { Name } \\
\text { Doreen Parker } \\
\text { Occupation nurse } \\
\text { Birth } \\
\text { 1938, Sheffield. } \\
\text { Marriage 1958, St Mary's, Sheffield, } \\
\text { now the cathedral. } \\
\text { Death } \\
\text { 2002, Swindon, Wiltshire. } \\
\text { Cause of Death } \\
\text { Deep Vein Thrombosis; Ovarian Cancer. }\end{array}$ & $\begin{array}{l}\text { Edmund Road, Sheffield. } \\
\text { Nurses home, King Edward } \\
\text { VII Orthopaedic Hospital, } \\
\text { Rivelin. } \\
\text { Nurses home, City General } \\
\text { Hospital, Sheffield. } \\
\text { High Storrs, Sheffield. } \\
\text { Arkley, Barnet, } \\
\text { Hertfordshire. } \\
\text { Marlborough, Wiltshire. }\end{array}$ & $\begin{array}{l}\text { Securely attached to mother Hilda. } \\
\text { Avoidant attachment to Walter. } \\
\text { Grew up in poverty with a Victorian father. } \\
\text { 1939-1945, WW2. } \\
\text { 1940, Sheffield Blitz. } \\
\text { Bullied at grammar school. } \\
\text { Left home at } 16 \text { and moved into nurse's } \\
\text { home. } \\
\text { Bullied during her later years of nurse } \\
\text { training. } \\
\text { 1962, miscarriage. } \\
\text { 1969, closet friend emigrates. } \\
\text { c1972, death of closest friend. }\end{array}$ & $\begin{array}{l}\text { Depression, battled } \\
\text { with excess weight. } \\
\text { Smoker. }\end{array}$ \\
\hline
\end{tabular}

\subsection{Attachment Theory}

Attachment theory was first proposed in the 1950s by British psychoanalyst John Bowlby. According to Bowlby, infants discover how safe, available, and trustworthy people are during their early months and years. Given a child's "immense and profound need to survive, a child will always develop an attachment relationship with his or her caregiver(s), no matter what the caregiver's characteristics are" (Blair-Gómez 2013, p. 36). Mary Main explained that if the important people in an infant's life are insensitive, cold, rejecting, unpredictable, or frightening, the child learns that others "cannot be counted on for support and comfort, and this knowledge is embodied in insecure or anxious working models of attachment" (Main quoted in Fraley and Shaver 2000, p. 3). Main added that the insecure child could excessively demand attention and care or withdraw from others and attempt 
a high degree of self-sufficiency. In contrast, an infant who is cared for in an attuned and consistent way develops a secure attachment and can live their life expecting others will be available when needed (Feeney et al. 2008).

Attachment theory is important in understanding our ancestors because "although a secure attachment can be gained through positive relationships in later life, our original attachment style often stays with us over our lifetime and can be transmitted in some form or other to subsequent generations" (Parker-Drabble 2020). So, what kind of attachment did Walter have to his mother, Ann? Modern parents who struggle with unresolved loss can display "a range of perplexing behaviors during parenting, including dissociative-like stilling, distorted and frightening facial and vocal expressions, and poorly timed, rough, or intrusive caregiving" (Fearon 2004, p. 255). However, Griffin (2020) pointed out that historically "harsh and distant mothering was not regarded as problematic or abnormal" but was part of a "widely shared cultural belief within many working-class families that mothers should not overindulge their children." This confusion between meeting children's emotional needs and spoiling or indulging them continued. Indeed, "psychoanalytic and behaviorist theories of the 1940s and 1950s presumed that infants would be clingier and more dependent the more their needs were satisfied" (Duschinsky 2020), whereas Blatz's work demonstrated that when children are confident their needs will be met, they become increasingly independent (Duschinsky 2020).

Canadian psychologist Mary Ainsworth (1913-1999) developed the "strange situation" procedure in order to observe the variety of attachment styles exhibited between mothers and children (Ainsworth and Bell 1970; Seymour 2013). In the procedure, the behaviors of 100 infants aged between 12 and 18 months were observed using one-way glass in eight situations lasting three minutes each. Ainsworth discovered that approximately $60 \%$ of the children became upset when the mother left the room but when she returned, the child actively sought the parent and was easily comforted. Children who exhibit this pattern of behavior are labeled "secure" and tend to have parents who are responsive to their needs. Around $20 \%$ or less of infants appeared uncomfortable when the stranger was in the room; and when separated from their mother, they became extremely distressed. When these children were reunited with their parents, they were difficult to soothe, often exhibiting conflicting behaviors that suggested they wanted to be comforted and "punish" the parent for leaving. These children are often called anxious-resistant. The third pattern of attachment that Ainsworth et al. documented was referred to as avoidant. Avoidant children (about 20\% of the group) did not appear particularly distressed by the separation. When the mother returned, these infants avoided seeking contact with their parents. Children who appear insecure (anxious-resistant or avoidant) often have parents who are either insensitive to their needs or inconsistent or rejecting in their caretaking style. Ballard (1993) found that children of alcoholic mothers were more likely to have an avoidant attachment style than children of non-alcoholic mothers.

According to Reisz et al. (2018), Bowlby later wrote about disorganized attachment that can replace a previous attachment when the child feels threatened in specific ways. He identified three circumstances when this might happen, first where there is a threat conflict, i.e., when someone previously associated with safety becomes associated with threat, for example when a caregiver is holding a child down to allow a medical procedure. Second, where there is safe haven ambiguity. Here, even if there are no cues for threat this too can change a child's normal way of reacting; for example, when the child is in a new situation that may appear to have no end. A third circumstance is known as activation without assuagement and is activated when a child has a long-time need for a safe caregiver, but they do not appear to sooth the child or help them name and regulate their feelings and emotions. For example, this might happen when a child is institutionalized in a workhouse or isolation hospital. Bowlby noted James Robertson's observation that when hospitalized children returned home in these circumstances, a child usually experienced dysregulated rage and/or despair. 
The consequence of these three experiences could lead to future disorganization when the child, or adult, experiences similar triggers, or has similar expectations, fears, or hopes evoked by the original circumstance. Bowlby noted in his clinical practice that "events could be kept from conscious attention. He used the term selective exclusion to refer to the way in which attention divides the field of awareness into the relevant and irrelevant, imaginable, and feasible" (Reisz et al. 2018, p. 122). In the short term, this may protect our ancestors from overload and further disorganization. However, Bowlby saw this need for defensive exclusion as the root cause behind avoidance and if it is needed repeatedly, our relative may have lost important life information, affecting their emotional growth, their relationships, and the ability to keep themselves emotionally stable.

It can be difficult to picture our ancestors' parenting, but Ann's alcoholism gives us an additional clue because we know that alcoholics rarely have securely attached children. According to Vungkhanching et al. (2004), children of alcoholics are at increased risk for attachment difficulties. As most addicts manifest immense distrust in their relationships, often avoiding emotional openness and intimacy with others, it seems likely that Ann had a problematic relationship with her children.

\subsection{Dysfunctional Family}

To manage the stress of a dysfunctional home life, Wegscheider (1981) proposed five personality styles in children of alcoholics: Hero, Scapegoat, Lost Child, Mascot, and Enabler. ${ }^{2}$ In this model, the Hero, often the eldest, takes responsibility and is usually a high achiever, a perfectionist, and/or a people pleaser. The Scapegoat is a rebellious and disruptive individual whose role is to take the spotlight away from the alcoholic parent. The Lost Child adapts by unknowingly repressing their thoughts, feelings, and needs, withdrawing into themselves, needing less adult attention, and often being overlooked. Lost Children may grow up to avoid intimate relationships, guard against anxiety or abandonment, and be fearful of risk or initiative. Perhaps Walter, who his nieces believed to be a shy, quiet lad, became the Lost Child, emotionally left to himself. The Mascot is the family clown who takes attention away from the dysfunction. They try to make people laugh despite the unaddressed psychological pain within the family. Finally, the role of Enabler makes all the other roles possible. They try to keep everyone happy, usually at the expense of their own needs. From my conversations with Mary, this role seems to have been fulfilled by Walter's father, Stephen. "He would do anything for anybody" and "tried to give his wife the best life he could."

An addict's family often develops unspoken rules such as "Don't talk, don't feel, don't trust." They commonly exhibit mood swings, along with inconsistent and erratic behavior. According to an article on the King University website, when drug or alcohol abuse exists in a family, "family rules, roles, and relationships are established and organized around the alcoholic and/or other substances, in an effort to maintain the family's homeostasis and balance." ${ }^{3}$ Individual family members can believe they have become adept at managing the alcoholic's behavior and are protecting the "shameful" secret of dependence. Instead, the behavior can lead to a cycle of insecure attachment, a predisposition to addiction, and learnt, damaging co-dependent patterns of behavior that may become part of the next generation's inheritance.

\section{Three Generations of the Parker Family}

"Research shows that the adversity we experience as a child can affect how our stress response functions, leading to long-term changes in our brains and bodies and leading to health problems as an adult. Experiencing 4 or more [adverse childhood experiences] ACEs are associated with significantly increased risk for 7 out of 10 leading adult causes of death, including heart disease, stroke, cancer, COPD, diabetes, Alzheimer's disease and suicide." 4 Research carried out by Felitti (2002) linked drug addiction, hepatitis, fractures, obesity, and alcoholism to adverse childhood experiences. As a family historian exploring my ancestors' lives, I expect to learn something from the past that helps me in the present (see Table of 
three generations of the Parker family). I seek historical empathy that requires "one to imagine the other's situation and what it might feel like, while simultaneously recognizing one's difference from them" (Landsberg 2009, p. 223). This differs from projecting our own beliefs, thoughts, and experiences on to our ancestors. It is more the "ability to appreciate the other person's feelings without yourself becoming so emotionally involved that your judgment is affected" (Lanzoni 2015). Its value is in creating what Alison Landsberg describes as prosthetic memory, one that is created from others' memories acquired from not only personal accounts, but also through mass culture. Through these means, we can understand past attitudes and ambitions, and the resultant empathy can become a tool for contemporary understanding (Craddock et al. 2018, p. 16).

\subsection{Ann Catherine Parker (1856-1938)}

Ann grew up in poverty and her young life was threaded with tragedy, but family historians know her experience was far from unique. However, research by Felitti et al. (2019) tells us that the number of adverse childhood experiences (ACEs) one has affects how we each respond to stress. This leads to long-term changes in the brain and body and to subsequent health problems as an adult. As we read about our ancestors' lives, it is worth noting that an adverse childhood experience includes the loss or separation of a parent or sibling, poverty, accident, or invasive medical treatment. We should also bear in mind that experiencing four or more ACEs is associated with significantly increased risk for 7 out of 10 leading adult causes of death, including heart disease, stroke, cancer, chronic obstructive pulmonary disease, diabetes, Alzheimer's disease and suicide. Earlier, Felitti (2002) specifically linked drug addiction, hepatitis, fractures, obesity, and alcoholism to adverse childhood experiences.

When she was four years old, Ann's mother died of consumption. Although we cannot know Ann's relationship with her mother, we know consumption kills slowly, so we can hypothesize that the attachment break when death came was traumatic. It would therefore have been natural for Ann to be anxious about the mortality of close family members. Saphire-Bernstein et al. have linked an inheritable gene to optimism, self-esteem, and mastery: the belief that one has control over one's own life. They further note that these three psychological resources "have been found to be significant predictors of effective stress management, neurophysiological responses to stress, and physical and psychological health-related outcomes" (Saphire-Bernstein et al. 2011, p. 15120). According to them, optimism, self-esteem, and mastery are critical psychological resources for coping well with stress and depression. However, McEwen and Akil (2020) reminds us that while it is not possible to "erase the biological consequences of experience, an individual's trajectory can be modified by additional experiences that can either enhance their ability to cope in a healthy manner or lead them to succumb to stress-related disorders" (McEwen and Akil 2020, p. 15). Sadly, Ann was unable to avoid alcoholism or cardiovascular disease.

Bowlby recognized that in grief and loss, a child uses their attachment style to cope with adversity and regain their sense of security. But who could Ann have turned to after the death of her mother? The 1861 Census shows Ann's then-only sister, Mary, was living with her in the family home. It is probable Mary was a mother figure for Ann, but Mary must have had her own issues. She, too, had experienced a multitude of adverse childhood experiences. Three of Mary's younger siblings had died before Ann's birth and at six years old Mary was listed as present at her five-year-old brother's death. It cannot have been easy for Mary to look after the impoverished family before and after her mother's death.

By the time Ann reached the age of six, her father had remarried. This relationship would have been particularly important because by the time Ann was seven, her sister Mary, aged 20, was married and living 30 miles away. Sotero (2006) and Colich et al. (2020) discovered that the physiological and psychological effects of overwhelming emotional experiences affect a person's lifelong health (Sotero 2006, p. 99). ${ }^{5}$ It is therefore likely that Ann's development, resilience, and long-term well-being were threatened by the death 
of her mother and siblings as well as her sister's move. Did Ann's ability to form close emotional attachments diminish after each loss? Ann's granddaughter, Mary, told me she could not recall a single time when Ann had laughed or even smiled, which reminded me of the first ever episode of Who Do You Think You Are? in 2004. ${ }^{6}$ The program described conservationist Bill Oddie's mother as an undemonstrative, difficult woman. Like Ann Parker she had suffered the loss of an infant. Mary remembered Ann as an unhappy alcoholic who was volatile and "difficult to get along with." ${ }^{77}$ Mary shared Bill Oddie's sentiment, "I wish I knew then what I know now, because I could have made a difference". Tragically, in Mary's case she had not been able to help her only child survive depression.

In England, school was not free or compulsory, and in Ann's poverty-stricken family she would have started work as soon as it could be found. The Census record of 1871 shows 15-year-old Ann had left Alconbury Weston, Huntingdon, and followed her sister to Upwell in Norfolk. Ann worked as a servant for a 63-year-old farmer and reported to the live-in housekeeper. Ann's move did not save her from further loss. Both her father and stepmother died in the workhouse before Ann's marriage to Stephen Parker in 1880. In October 1883, Stephen and Ann's firstborn died of tubercular meningitis at 18 months, when Ann was approximately 24 weeks pregnant with her second child, Ethel.

In light of her sister Mary's loss of four babies, it is plausible that Ann may have viewed the birth of her children with some ambivalence and distress, which could have been transmitted to Walter (Yehuda and Lehrner 2018). Certainly, it seems that Ann paid an emotional price for the traumas she suffered. Although there is a common belief that our ancestors were less affected by loss, disaster, and trauma than we are, Hilary Marland, professor of history at the Center for the History of Medicine at the University of Warwick, makes a convincing case that poverty contributed to and exacerbated the mental suffering of women in Victorian Britain (Strange 2006, p. 471). That the poor were somehow immune to the loss of their loved ones is also soundly contested by Julie-Marie Strange, professor of modern British history at Durham University. In her book about death, grief, and poverty, Strange (2012) explained that poverty increased rather than deadened the anguish of the poor.

While it is possible Ann resolved her trauma and integrated a new understanding that allowed her to respond differently to her children, it is more likely that the traumas associated with her loses weakened her resilience to what was to come. It is impossible to say if Ann's parenting was considered unusual toward the end of the nineteenth century, but genealogists would probably understand if Ann unconsciously emotionally distanced herself from Walter and his siblings to protect herself from further loss.

\subsubsection{Ann's Addiction to Alcohol}

Although Ann's grandchildren, Mary, and Rene believed she was addicted to alcohol all her adult life, neither knew the trigger. ${ }^{8}$ Ann's alcohol use disorder was not named within the family but referred to as Ann's "condition." Vaillant (2009) suggested a challenging childhood environment "is an important predictor of when an individual loses control of alcohol." Nickerson et al. (2013) noted that "the younger the child was at the time of loss [of a parent], the more likely the child was to develop mental health problems, including anxiety, mood, or substance abuse issues" (see also Lovett 2014). Therefore, Ann's bereavements or fear for her children's lives may have made her more vulnerable to alcohol misuse disorder and poor mental health. ${ }^{9}$ The Austrian neurologist and founder of psychoanalysis, Sigmund Freud, described "melancholia as an acutely painful and unresolved form of mourning, associated with 'self-reproaches', 'self revilings' [sic], and 'a delusional expectation of punishment'" (quoted in Lapping 2019). In a more recent study, Solomon (2001) has explained that the same genes and neural pathways that can make us more vulnerable to depression are also involved in anxiety, alcoholism, and suicide. ${ }^{10}$

Why did Ann drink to excess? Schindler (2019) showed that alcohol might be used to reduce social fears and help those with a preoccupied style of attachment feel closer to others. Individuals with preoccupied (sometimes called ambivalent/enmeshed/anxious) 
attachments often try to elicit care and support through clinging and controlling behavior (Shaver and Hazan 1993). These efforts at closeness are not only used to establish physical contact but aim to foster a sense of intimacy, similarity, and oneness with a romantic partner (Mikulincer and Shaver 2003). Such strategies are also indicated by an overdependence on relationship partners (Shaver and Hazan 1993) and the preoccupied person's belief that they are helpless and incompetent at managing their own feelings (Mikulincer and Florian 1998). These individuals can also be preoccupied with their own distress and other people's availability to help them cope. "Avoidant or fearful individuals, on the other hand, are uncomfortable with closeness and might use higher doses [of alcohol] to avoid contact and deactivate emotions" (Schindler 2019, p. 727). People with an avoidant style lack attachment security and are compulsively self-reliant, with a preference for staying emotionally distant from others. Reisz et al. (2018) pointed out that "avoidance is a rigid, brittle form of organization with significant disadvantages, such as not seeking help when needed or even registering the need for help."

However, while a child's relationship with their parents is considered important, other factors should be considered. The research of Fraley and Shaver (1997) on adult attachment revealed two avoidant groups. The first group, fearfully avoidant, are afraid of emotional bonds and feel high anxiety, but can long to be in a loving relationship. The second group is known as dismissing avoidant. According to Connors (1997), dismissing avoidants believe "renunciation of love is preferable to the pain and [perceived] danger of relationship; instead, they seek control and mastery over the environment" (Connors 1997, p. 476). Dismissing avoidant adults experience low anxiety and do not fear rejection or loneliness. Indeed, Fraley and Shaver discovered that when dismissing individuals were instructed to suppress their thoughts and feelings; they were able to minimize the attention they paid to thoughts. After speaking to two of Ann's grandchildren-Mary and Rene-at length, I wondered if Ann had an avoidant style. Walter appears to fit the description of the dismissing avoidant style.

Although Ann's demeanor as described by Mary and Rene cannot be symptomatic of an alcohol use disorder, we can surmise that the emotional blows Ann received, and a likely insecure attachment style, diminished Ann's ability to cope with the tragic death of her first child. Given that children currently brought up in poverty are at an equal risk of forming an insecure or disorganized attachment as children who have been mistreated (Voges et al. 2019), it would appear unlikely that Ann grew up with secure attachments. It would have been remarkable if Ann had avoided anxiety or depression, either or both of which could have been the precursor to her drinking, possibly triggered by postnatal depression or genetic inheritance (Prescott et al. 2000, p. 808; Womersley et al. 2021, pp. 33-34). ${ }^{11}$

\subsubsection{Grief}

It is also possible that Ann suffered from a prolonged grief disorder (PGD). Researchers have explored how symptoms of PGD and depression co-occur in the bereaved. Kokou-Kpolou et al. (2021) have looked at the this in light of the revised definition of PGD in the new edition of Diagnostic and Statistical Manual of Mental Disorders (DSM-5) (Boelen et al. 2020, p. 1771008). Kokou-Kpolou's investigations might be particularly useful because it is a nonwestern study in a "region of the world where the mortality rate is very high and consequently bereavement issues are a major health concern" (Kokou-Kpolou et al. 2021). The researchers also considered the potential impact of sociocultural and religious factors. Their findings might therefore raise possibilities about Ann's possible experience. Their results "identified a resilient class (20.6\%), predominantly PGD class $(44.7 \%)$, and combined PGD/Depression class $(34.7 \%)$. . age, time elapsed since the loss, continuing bond and relationship with the deceased, as well as spirituality were the differential predictors of class membership" (Kokou-Kpolou et al. 2021) "Younger people were found to be more at-risk to endorse pervasive symptomatology." More recently, bereaved individuals were likely to belong to the PGD class, and those who mourned the death of an immediate family member were more likely to belong to the combined 
PGD/Depression class. Those in these later classes also reported a higher level of continuing bond with the deceased. Reading this, I was reminded that the large elaborate funeral card given to Ann and Stephen in 1883 after the death of their daughter is the only item associated with Ann that has survived. Could this be indicative of an association between bereavement complications and high levels of post-loss attachment to the deceased found in the studies of Boulware and Bui (2016) and Gillies and Neimeyer (2006)? Lower levels of spiritual beliefs were associated with the predominantly PGD class, which might be associated with a difficulty in accepting and finding meaning in the loss. Kokou-Kpolou pointed out that a belief in a god or understanding death to be an integral part of human existence "may offer comfort and consolation at time of loss and facilitate the mourning process" (Kokou-Kpolou et al. 2021).

Others have looked at the impact of grief and attachment style. According to Maccallum and Bryant (2018), "it is possible that attachment avoidance contributes to bereavement complications, such as depression, by reducing the likelihood that an individual will utilize available social supports or develop new attachments." Furthermore, Lai et al. (2015) found that "female gender, high levels of depression, and preoccupation with relationships significantly predicted higher levels of prolonged grief risk." Sochos and Aleem went further in their finding that where there is complicated grief parental attachment insecurity may facilitate that transmission intergenerationally (Sochos and Aleem 2021, p. 14).

\subsection{Walter Parker (1885-1975)}

\subsubsection{Possible Consequences of Ann's Trauma}

We know that the effects of a parent's unresolved trauma can be passed on to their children. Author Marianne Hirsch described 'postmemory' as "the relationship of the second generation to powerful, often traumatic, experiences that preceded their births but that were nevertheless transmitted to them so deeply as to seem to constitute memories in their own right" (Hirsch 2008, p. 103). While I have no evidence of this for Walter, given the ongoing danger of meningitis, TB, fever, and more, which led to Ann's losses, it seems almost inevitable that Walter too was aware that he or his sisters, cousins, and peers could also die young. ${ }^{12}$ According to Beiner (2014), intensive "remembrance is retained beyond personal recollections of those who experienced historical events and can be transmitted over three generations as a fluid 'communicative memory' (in which grandparents pass on vivid narratives to grandchildren and their peers) before it is formulated into a more stable form" (Beiner 2014, p. 303). Although an awareness of death is likely to be intermittent, it was not only family, friends, and neighbors who could bring it to the forefront. ${ }^{13}$ Newspapers also reminded people of their mortality through the annual death report in each area as well as the daily obituaries report. ${ }^{14}$

Traumatized parents can struggle with debilitating depression, unexplained grief, and an increased vulnerability to stress without understanding the cause (Kirmayer et al. 2000). It was sobering to learn that "the absence of emotional support early in a mother's life, years before conception, are also associated with neural changes ... in her offspring shortly after birth" (Hendrix et al. 2021, p. 470) "found that the more emotional neglect a mother had experienced during her own childhood, the more strongly her baby's amygdala was connected to the frontal cortical regions" "which has been associated with an increased risk for depression and anxiety across the lifespan" (Elsevier 2021; Hendrix et al. 2021, p. 470). Therefore, it is reasonable to consider that Walter and his siblings may have inherited intergenerational consequences from their mother's early life adversity and depending on their life experiences, passed a toxic legacy onto their children.

Another consequence of Ann's experiences could have been an inability to react appropriately to her children. 
Iyengar et al. comments:

"A mother with preoccupied unresolved trauma may be hyper-vigilant in response to her infant's distress, while a mother with a denied unresolved trauma may under-respond to her infant's distress". (Iyengar et al. 2019, p. 110)

Kim et al. (2014) also studied mothers with unresolved trauma, discovering that the amygdala, the part of the brain that processes emotion and memory, was turned on when viewing unknown children but was turned off when the mother looked at her child's distressed or happy face. We can speculate that this inability to recognize her children's suffering protected Ann from reexperiencing her own trauma but could have left Walter and his sisters psychologically "alone," with no mother to mitigate or help process their emotional pain (Iyengar et al. 2019, p. 110). This unconscious defense mechanism could also explain, in part, how a transgenerational transmission of trauma can be inherited.

According to Sochos and Aleem (2021), "both parental attachment anxiety and avoidance increase the impact of parental complicated grief on child traumatic stress." Anxiously attached parents who also struggle themselves to accept an important loss would be expected to display more exaggerated parental inconsistency between overprotecting and emotionally neglecting the child. On the other hand, avoidant parents tend to suppress negative emotion both in themselves and their children (Edelstein and Shaver 2004) and would be expected to do so more intensely when they also experience sadness and despair relating to an unresolved loss." (Sochos and Aleem 2021, p. 14). We can also consider that Sochos and Aleem concluded "Psychological vulnerability in bereaved young persons was associated with an insecure parental attachment style (Sochos and Aleem 2021, p. 15)."

\subsubsection{Walter's Attachment Style}

Bowlby postulated that people with attachment-related avoidance-those who withdraw from a parent-prefer not to rely on other people or open up to others when they are distressed. Considering the work of Bowlby and Ainsworth, we might conclude, as well as we can, that Walter had a dismissing avoidant attachment style, perhaps echoing his mother's style (Kelley et al. 2010, p. 1558). Certainly, Zelekha and Yaakobi (2020) found that the more avoidant the mother, the greater likelihood the male in the next generation will be avoidant. Kelley et al. discovered that people who suspected their mothers of alcoholism reported a more avoidant overall attachment style in romantic relationships (Kelley et al. 2010, p. 1565). However, we should not assume Walter did not need to feel close to people, rather that he had buried his need (Carvallo and Gabriel 2020). Perhaps because Walter did not appear to suffer from painful rumination, he could be perceived by others as uncaring (Turan et al. 2016, p. 234).

As avoidant parents tend to distance themselves emotionally from distressing events and experiences, their bereaved children may also adopt that strategy (Grossmann 1989). However, emotionally distant, avoidant parents provide relatively consistent care, potentially helping their children maintain a sense of stability as they deal with the disruption of death (Sochos and Aleem 2021, p. 13).

\subsubsection{Ann's Alcoholism and Depression}

Nineteenth-century opinions of alcoholism were replete with moralistic overtones. Professor of modern British history, Emma Griffin notes in her book Bread Winner that "drinking was quite easily incorporated into narratives about fathers, but alcoholic mothers were an object of shame" (Griffin 2020, p. 248). In 1878, Ann may have been aware of the feeling a female writer expressed when she wrote that a man should be excused of domestic abuse if he had the "universally condemned creature, the drunken wife" (Cobbe 1878, p. 69). One can imagine the humiliation and shame Walter and his siblings might have felt at having an alcoholic mother. Walter was likely deeply affected by Ann's understandable depression. A paper from Lupien et al. explained that depressed mothers "have been associated with reductions in overall sensitivity to the infant, and with an increased rate of withdrawn, disengaged behaviors" (Lupien et al. 2011, p. 14324). A child of a depressed 
mother can be so adversely affected that their enlarged amygdala is comparable to the changes found in an infant's brain when a mother has been wholly absent from their life. Qin et al. (2014) reports that high childhood anxiety is associated with enlarged amygdala volume. Further, "sustained anxiety in children may bias this system toward withdrawal or avoidance behavior to alleviate anxious states."

\subsubsection{Mitigating Factors}

Whatever happened in Walter's childhood, ground-breaking research by Zelekha and Yaakobi (2020) suggests optimistic possibilities. These researchers provided empirical evidence that stable experiences throughout adulthood-for example, the birth of a child or changes in income and employment status-are likely to moderate intergenerational transmission and influence people's attachment orientation in adulthood. Zelekha's team explored the positive role that "intimates, friends, and even the work environment" can have in changing attachment style, making attachment a lifelong process rather than a condition fixed in childhood (Zelekha and Yaakobi 2020, p. e0233906).

Furthermore, although Beletsis and Brown (1981) noted that female alcoholism is generally associated with personal problems and that higher numbers of depression and anxiety disorders are found in alcoholic women (quoted in Saatcioglu et al. 2006), Qin et al. discovered:

... changes may confer some adaptive advantages for developing balanced strategies to cope with challenging and stressful situations in real life. (Qin et al. 2014, p. 898)

It is clear that Walter's young life was not solely dysfunctional. His parents, teachers, community, and early employers helped him gain practical skills. Indeed, Simpson and Belsky (2008) suggested that the "inborn attachment bias can be channeled in different directions and can [also] be either secure or insecure as a function of the way parents prepare [their offspring] to survive and adapt to a specific bio-ecological niche" (Zelekha and Yaakobi 2020, p. e0233906). The consistent nurturing, acceptance, and encouragement that Walter's granddaughters described receiving from their grandfather may have mitigated the negative effects of Ann's behavior in Walter. This desire on my part is not without basis in scholarship, as attachment theory allows that children can have different attachment styles with each caregiver, and Zelekha and Yaakobi (2020) commented that fathers and mothers have differing effects on their male and female attachment orientations. Strange reported that shared experiences between fathers and sons helped them to (re)discover a common language when they took up apprenticeships or joined the world of work (Strange 2012, p. 1020). Walter's agricultural work and his apprenticeships echoed his father's successful path in providing for a wife and family, which may have created an additional bond between them.

We know that Stephen moved away from his home village, where he appeared to have a good living as a carpenter and builder. It is important to consider that Stephen's duties for the Duke of Bedford in Thorney might have allowed him a closer relationship with his children, because he probably worked more predictable and fewer hours than he had when he was self-employed and likely ate all his meals with his family.

\subsubsection{Walter Comes of Age}

In 1907, at the age of 21, Walter left The Tank Yard in the close-knit Thorney village for Canada. He likely wore a money belt under a full set of thermal underwear and carried a rucksack on his back that was packed with a new leather notebook, a multi-purpose pen knife, a fork, a tin mug and plate, a flask of water, a cutthroat razor, brush and soap, a flannel, a change of clothes, and a set of basic carpentry tools. His companion was his neighbor and chum Ernie Kitchen, a recently qualified plumber. The two friends took out adjoining 160 acre plots and helped each other meet the stringent requirements to keep their land, but successful bachelor homesteaders were rare. ${ }^{15}$ The men each had to cultivate at least 40 acres and build a permanent dwelling within three years of taking on their 
plot. This demand was brutal on the body, and the isolation and loneliness could cause great distress in even the hardiest pioneers (Joinson 2018). Homesteaders on the prairies of America and Canada were known to be at risk of prairie madness. In 1893, E.V. Smalley, the editor of Northwest Illustrated Monthly Magazine, said, "An alarming amount of insanity occurs in the new prairie States among farmers and their wives" (Joinson 2018) Walter's neighbor Ernie later traveled to England and returned with a wife, but reticent Walter kept a dog for company. Was Walter particularly at risk of prairie madness, given his inheritance from his depressed mother?

We know avoidant-attached adults tend to seek isolation and independence. But even without the isolation he experienced on the prairies, if Walter had an avoidant insecure attachment to his mother, he may have found it difficult to provide emotional support to others. Certainly, such adults can avoid relationships in an attempt to prevent disappointment and rejection. Was it also hard for him to trust and depend on people? Might Walter have unconsciously been escaping the discomfort of intimacy by creating a bachelor homestead on the prairie?

\subsubsection{Walter's Return}

Walter returned to England during the Great Depression. Jarrett (2019) pointed out that "mid-life - when anxiety and avoidance tend to decline-is arguably the time when we are most invested in various social roles and relationships". True or not, 51-year-old Walter was to propose marriage to a 36-year-old spinster housekeeper. According to my mother, Hilda asked newly arrived Walter to help her when she tragically found her employer hanging in an out-building. Their relationship blossomed despite its macabre beginning, and they kept in touch, although Hilda had to move to take up a live-in job in Welwyn Garden City, England, while Walter found them a home.

In the 1930s, those without qualifications, skills, or family to rely on lived in a desperate state. For a time, Walter moved in with his elderly parents, who supported themselves with a small parlor shop that sold single cigarettes, tobacco, and sweets in twists of paper. Walter struggled to find long-term work and clung to his hard-won savings, not knowing how long it would be before he found secure employment. Understanding how difficult it would be to find affordable board and lodgings, he concentrated his search in an area where he had family. Before his marriage to Hilda, Walter's training and experience as a carpenter and joiner enabled him to secure work for the London, Midland, and Scottish Railway. He lodged with his youngest sister Lucy, brother-in-law Fred Snr (a war hero), and nephew Fred Jnr. I expect his bed was in the attic space of the two up, two down terrace half a mile from the Sheffield Midland station in the center of industrial Sheffield. It is difficult to imagine a starker contrast with village life in Thorney or his life in Canada.

Another desperate act touched Walter and Hilda's life when his brother-in-law lay down in front of a steam engine. The family story is that Fred Snr could not live with the shame of his infidelity. The coroner ruled his death an accident, despite indications that it was not. which allowed insurance to pay for the funeral. However, Lucy could not support herself and her son in Sheffield, so they returned to Ann and Stephen in Thorney. Walter took over the tenancy agreement of Lucy's small, terraced house with an outdoor privy. ${ }^{16}$ He now had a secure job and a home and could marry Hilda.

Earlier, I concluded that Walter might have had a dismissing avoidant attachment style that an attentive father could have somewhat mitigated. During the decades Walter spent mostly alone in Canada, his style was unlikely to have changed. Whatever Walter's attachment style, I surmise from his bachelor homesteading in Manitoba that he was mostly self-sustaining and comfortable, without a physically present relationship. On his return to England, I imagine Walter made a pragmatic decision and looked for a spouse who would manage their domestic arrangements with whatever housekeeping money he gave her. This would not have been too out of step. In the early 1930s, The Matrimonial Post and Fashionable Marriage Advertiser established in 1860 still showed how important gendered roles were in hopeful readers. A "commitment to domesticity 
was paramount: both spinsters and bachelor clients requested "homely" individuals" and "steadiness was a much sought-after attribute." Walter may also have expected a younger wife to care for him in his old age. Women of the period looked for "a husband capable of providing reliable financial support and a home within which to bring up a family" (Langhamer 2013, pp. 24-25, 54). What marriage meant for Hilda is impossible to say, but it is worth noting that she was born when her father (another railway employee) was also 51 years of age and the age difference between her mother and father was very similar to the years between herself and Walter. Any sense of security Hilda's parents gave her was a memory, as both had died before she was 17 years old. Hilda spent much of her life living with an untreated thyroid condition, so swapping her role as a live-in housekeeper in a four-bedroom dwelling to become a wife living in a small terrace might have offered her much-appreciated security. ${ }^{17}$ Cousin Mary said that Hilda had always wanted children but had given up hope of motherhood. Her successful pregnancy was remarkable, given she had hypothyroidism. I hope Hilda received more comfort and support from her husband than an avoidant attachment style might suggest.

\subsection{Walter's Daughter Doreen Parker (1938-2002)}

\subsubsection{Doreen's Parents}

Mom told me she was a welcome surprise for her 37-year-old mother but a shock to her father. ${ }^{18}$ I do not know if Walter was reminded of his own childhood and whether this raised any demons from his past or fears that he thrust aside. In the last years of her life mom told me that she experienced Walter as "distant" and "emotionally absent." I expect Walter displayed some of his mother's parenting. Avoidantly attached individuals can feel burdened when asked to care for others, including their own children. This means they can be somewhat negligent, emotionally distant, and less responsive to their children, particularly if the children become highly distressed (Fraga 2018). When their offspring is most upset and in need of parental support, the avoidant parent may not have the skills to soothe and reassure their child. Doreen tried to get closer to her father, who as a son of an alcoholic, may have struggled to identify or convey his conscious feelings or the emotions he experienced. It would appear Walter could not be the father Mary believed her grandfather had been.

From about seven to nine months, infants will frequently have a special preference for a single attachment figure. The baby looks to this person for security, comfort, and protection. ${ }^{19}$ No doubt Hilda was mom's primary attachment, but I believe Hilda also a had a tale to tell. Hilda had several live-in domestic jobs before her marriage. She presumably found a way to fit in, but two photos we have of her, one as a large, awkward teenager dwarfing her parents and the other in the uniform of a domestic servant trying to disappear into a hedge, suggest a young person who did not want to be seen. My impression is of a woman who was not sure of herself, and I was not surprised Mom told me that Hilda smothered her.

Meanwhile, I believe Walter's focus was to support his family in uncertain times, so he concentrated on his role as breadwinner. Although the workhouse system had come to an end in 1930, the newly named Public Assistance Institutions operated in a similar way. People continued to refer to the buildings as workhouses, and the dread of these cast a long-lasting shadow. With no work experience in England, no insurance, and a deep economic depression, my grandfather knew losing his job would cause his family severe hardship. The men who could not support their families had to surrender to the intrusion of comprehensive means testing carried out by insensitive officials in return for very little money. Walter saw this option as abhorrent charity and did everything he could to avoid receiving unemployment assistance.

\subsubsection{Life in Sheffield}

While Walter understood he had to live where there was work, he could not have felt a house in the industrial center of Sheffield, where gang wars had resulted in police brutality 
and corruption, was the best place to raise his child. Nor could he have seen much of Doreen, for he probably worked $48.6 \mathrm{~h}$ a week over six days, with overtime when he could get it (Huberman and Minns 2007, p. 542). When war broke out in September 1939, mothers with children under five were evacuated from cities and towns thought to be military targets. Those who had family they could stay with made their own arrangements. ${ }^{20}$ Hilda told Doreen that they had evacuated for a short time. ${ }^{21}$ As East Anglia had been proposed to accommodate refugees from Sheffield in 1938, Hilda might have thought it reasonable to take Doreen to her sister Minnie, living in the relative safety of Peterborough. However, it would have been a tight squeeze in the Matthews' little Victorian terrace, which already housed three adults and two children.

In 1921, the Canadian Census defined Walter as "Canadian", and it must have been hard for Walter to let this identity go. According to Rollero and Piccoli (2010, p. 199), it takes time for us to become a member of a new social group and to modify our identity, but in a few short years Walter had found work in a Depression, taken on a tenancy, married, learned to accommodate a wife and city living, become a father, and joined the heavy rescue squad. These experiences, Walter's age, and the danger to his family may have helped him reinvent himself and bond more easily with others. His work in the rescue squad was to shore up damaged walls and floors so the search for survivors could begin. Whatever Walter's attachment style in the few hours he was at home with his family, he would have been exhausted and it could have been difficult for him to be emotionally present.

Writing this article reminds me of the proverb, "It takes a village to raise a child." (Seymour 2013, p. 115). Research has shown the value of children having multiple attachments, but it takes different forms, according to the local environment and culture (Seymour 2013). While Walter may have found a sense of belonging through his work, Hilda and Doreen lived a much more restricted life at home. However, despite their austere life, I hope they found a welcoming community and friends at a local mother and baby clinic or in the shelters during a bombing raid (McIntosh 1997).

Walter and Hilda's psychological legacy and the poverty they endured meant their daughter was initially socially isolated, but her voracious reading was fueled by the weekly trip to the library with her parents. Doreen's knowledge grew and fed into the homework she poured over at the kitchen table. The Girl Guide movement offered her an escape from her claustrophobic home life, first as a Brownie and later as a Girl Guide. The movement aimed to encourage the development of the whole person. Doreen promised to 'help other people at all times' and obey the Guide Law which included vows to be trusted, loyal, thrifty, and to smile no matter what difficulties beset her. ${ }^{22}$ She thrived in its no-nonsense practical environment. Doreen passed the competitive examination known as the elevenplus, which gave her access to the local grammar school. Unlike some of her friends, she was able to take up her place because Walter paid for the expensive but compulsory school uniform. Although Walter was silent on the subject, I hope he knew that this support gave Doreen the chance to reinvent herself and apply for nurse training.

\subsubsection{Doreen's Attachment Style}

Conversations with my mom, Doreen, dad, and Doreen's lifelong friend, Sheila, led me to believe Hilda probably had an anxious or preoccupied attachment style to her mother, which gave her an "emotional hunger that unintentionally drained" Doreen and acted "as an unfulfilling substitute for real love and nurturance" for Hilda (Firestone 2013). Doreen experienced this as clinginess and a desire to be over-involved in her life, although Doreen welcomed the mothering she had from a friend's mother. ${ }^{23}$ Hilda, desperate to hold onto her relationship with her daughter, sadly alienated her further by repeated, comprehensive apologies that encouraged Doreen to become fiercely independent. ${ }^{24}$

However, it is difficult to reach a conclusion about Doreen's attachment to Walter. I wonder if she had an avoidant attachment to Walter, as this has much to do with the emotional availability of a parent. Although her father did not physically neglect her, I suspect he avoided displays of emotion and intimacy and was mistuned to her emotional 
needs. Those with an avoidant attachment to a parent are often reserved and seem to back off when their child reaches out for support, affection, and reassurance. Walter probably felt overwhelmed and became increasingly distant when someone around him expressed strong feelings. Young Doreen might have expressed a need for closeness, but instead of receiving it, Walter withdrew. To a child, this can feel like a door has violently slammed in their face. Parents like Walter might not only avoid expressing their feelings, but they can also shut down their children's emotions by silent disapproval or lectures about how they need to grow up or toughen up. Given Walter's psychological inheritance, he might have particularly reacted to Doreen showing anxiety, fear, or sadness; instead, he might have expected her to be self-reliant, serious, and reserved. Doreen could have adapted by "developing a pseudo-independent stance (i.e., I can take care of myself)" (Firestone 2013).

The picture of Doreen's attachment to her father is confused, perhaps in part because Doreen left home at the age of 16 to train as an orthopedic nurse. Because she could not afford the bus fare home, Doreen experienced isolation at the hospital where she lived and worked. Children and adult patients with tuberculosis, congenital deformities, and poliomyelitis lived in the hospital for months, sometimes years. The attachments these children had to their family was broken, as the nursing profession, ignorant of children's attachment needs, gave the distraught children only the physical care they needed believing "within a few hours or a few days he would "settle down" [and] would "forget" his mother" (Barnett and Robertson 1991, p. 12). As children have a biological need to attach, it is understandable that they reached out to the young homesick nurses. Although professional distance was demanded from the students, they often eased their own loneliness and fulfilled their patients' need for meaningful connections in the quiet of the night shifts while they were in charge of the wards. The student nurses were taught to be observant of any change in their patient's condition. They were rigorous in their hygiene practices and were encouraged to predict what a patient needed before the patient knew they needed it. During the isolated and demanding training, Doreen became close to two nurses, and the small group became her surrogate family. Although the student nurses were ruled with a "rod of iron," their support of each other also led to games and singing and joking with patients. ${ }^{25}$

Doreen was a deeply empathic woman whose training gave her the tools to recognize people's needs and enable them, not just to cope but to thrive, despite their challenges. Mohammadreza Khodabakhsh explains, "empathy plays a key role in the nurse-patient relationship because it promotes an understanding of the patient's emotional status and perception and helps the nurse to effectively share or participate in the patient's experience" (Khodabakhsh 2012, p. 2). This ability to be empathic suggests Doreen's infant attachment with her mother was a secure one. Further evidence of a secure attachment may be Doreen's decision to deliberately choose roles where she had the most interaction with patients, rather than follow a career path that became managerial (Khodabakhsh 2012).

Nursing can attract compulsive adult caregivers who were defensive precocious caregivers in childhood (Taggart and Elsey 2021). But while Bowlby identified compulsive caregivers who deny their own needs and focus on the needs of others this does not fit my experience of Doreen (West and Keller 1991). She did not seek out or continually care for, or rescue others around her. Nor did Doreen appear to feel responsible for her parents. After leaving the family home aged 16 Doreen did not spend significant time with either parent until Walter moved into our family home when Doreen was 36 years old.

Although Doreen battled depression, I do not believe she knew of her grandmother Ann's trauma, catastrophic losses, alcoholism, or depression. If she had, I believe she would have recognized the intergenerational threads of anxiety and depression she and some of her cousins suffered. Neither Walter nor Doreen knew they had received a toxic psychological inheritance, but they both strived to give their children better parenting than they had known. Throughout Doreen's life, she was valued as a trusted, loyal, and thrifty person, and a safe attachment figure for some of the insecure adults around her who needed support. Mom often smiled no matter what anxiety, fear or difficulties beset her. 


\section{Conclusions}

In this article, I explored three generations of the Parker family using key theories to show how a psychologically informed understanding of our ancestors can help family historians better understand their forebears, themselves, and living family. At the end of this research, I have come to believe each generation did what they could to leave a healthier legacy than the one they had inherited. Despite a difficult relationship with his mother, Walter grasped the opportunities his apprenticeship gave him. He emigrated and used his skill to build enough capital to become a farmer on the Canadian Prairie. Back in England, he did not expect to become a father, but he was able to support himself and his family during the Great Depression. However, Doreen grew up knowing her parents had few resources and that Walter and Hilda's future was precarious. I could not witness my grandfather Walter's informative years. Still, I wonder if what his daughter saw as Walter being an anachronism, an emotionally absent father stuck in the Victorian age, was as much about his psychological inheritance, attachment style, and the coping mechanisms he developed as a child. ${ }^{26}$

We cannot know our ancestors' psychological inheritance, that is the inherited traits, reactions, and patterns of behavior we inherit from our parents that are central to this paper. However, by the cautious exploration of theories, we can ask new questions and consider repeated patterns such as loss, depression, or addiction. With this information we can speculate about our ancestor's psychological inheritance in an informed way. The psychological genealogy we suspect or uncover can be shared with family and can inform health professionals. ${ }^{27}$

My hope is that family historians will increasingly uncover and share not only their family stories, and local and social history, but consider and share their family's possible psychological inheritance as well. We are in a privileged position. So much more is known about mental health, mental disability, mental distress, and how the effects of insecure attachment, adversity, and trauma might be reversed. Many of us are fortunate not to live in a culture that routinely silences those who struggle emotionally. Many can access evidence-based self-help and "find the places, the spaces, and the people that fit who we really are and allow us to live our best lives" (DePaulo 2016; Castañón 2020). Others share what they learn about their family with a therapist. However we choose to use our deepening understanding of our ancestors, we can remember the "past does not have to define ... us, 'it can empower us'" (Evans 2021, p. 98) The insight we gain can give living family new opportunities to thrive and pass on a healthier psychological legacy.

Funding: This research received no external funding.

Acknowledgments: Consultant George Regkoukos; external reviewer: Debanjali Biswas.

Conflicts of Interest: The author declares no conflict of interest.

\section{Notes}

As Asmussen et al outlines in "Adverse Childhood Experiences" (Asmussen et al. 2020).

The work of Hinrichs et al. noted the five personality styles are not exclusive to adult children of alcoholics (Hinrichs et al. 2011): pp. 487-98.

3 Defining the Traits of Dysfunctional Families, King University Online (2017). King University Online. https: / / online.king.edu / news / dysfunctional-families/ (accessed on 12 October 2021).

4 See the impact sudies of ACEs in "How Aces Affect Health" (2021) https://centerforyouthwellness.org/health-impacts/\#: $\sim$ :text=Experiencing\%204\%20or\%20more\%20ACEs, \%2C\%20diabetes\%2C\%20Alzheimers\%20and\%20suicide (accessed on 12 October 2021); Felitti et al. "Childhood Abuse and Household Dysfunction" (Felitti et al. 2019).

5 “Experiencing Childhood Trauma Makes Body and Brain Age Faster: Findings Could Help Explain Why Children Who Suffer Trauma Often Face Poor Health Later in Life". Sciencedaily. (2020) American Psychological Association. https://www.sciencedaily. com/releases/2020/08/200803092120.htm (accessed on 12 October 2021).

“Who Do You Think You Are?", (2004). TV programme. BBC 2: BBC.

From an interview with Phyllis Mary Skells, née Woods, known as Mary (2015). 


\section{References}

Ainsworth, Mary D. Salter, and Silvia M. Bell. 1970. Attachment, Exploration, and Separation: Illustrated by the Behavior of One-Year-Olds in a Strange Situation. Child Development 41: 49-67. [CrossRef]

Asmussen, Kirsten, Freyja Fischer, Elaine Drayton, and Tom McBride. 2020. Adverse Childhood Experiences What We Know, What We Don't Know, and What Should Happen Next. Early Intervention Foundation. Available online: https://www.eif.org. uk/report/adverse-childhood-experiences-what-we-know-what-we-dont-know-and-what-should-happen-next (accessed on 12 October 2021).

Ballard, Mary E. 1993. Adult children of alcoholics: Security, avoidance, and ambivalence in attachment to parents. Paper presented at the Meeting of the Society for Research in Child Development, New Orleans, LA, USA, March 25-28; Available online: https: / / files.eric.ed.gov / fulltext/ED357312.pdf (accessed on 12 October 2021).

Barnett, Lynn James, and Joyce Robertson. 1991. Separation and the Very Young. London: Free Association Books.

Beiner, Guy. 2014. Probing the Boundaries of Irish Memory: From Postmemory to Prememory and Back. Irish Historical Studies 39: 302-303. [CrossRef]

Beletsis, Susan G., and Stephanie Brown. 1981. A developmental framework for understanding the adult children of alcoholics. Journal of Addictions and Health 2: 187-203. 
Blair-Gómez, Carolina. 2013. The Biological Basis of Parent-Infant Attachment: Foundations and Implications for Further Development. Informes Psicológicos 13: 23-40.

Boelen, Paul A., Maarten C. Eisma, Geert E. Smid, and Lonneke IM Lenferink. 2020. Prolonged grief disorder in section II of DSM-5: A commentary. European Journal of Psychotraumatology 11: 1771008. [CrossRef] [PubMed]

Boulware, Dessirae L., and Ngoc H. Bui. 2016. Bereaved African American adults: The role of social support, religious coping, and continuing bonds. Journal of Loss and Trauma 21: 192-202. [CrossRef]

Carvallo, Mauricio, and Shira Gabriel. 2020. No Man is an Island: People Who Say They don't Need Other People Actually Care about Close Relationships ISPSP. Available online: https:/ / www.spsp.org/news-center/blog/carvallo-gabriel-dismissive-avoidantsbelonging (accessed on 12 October 2021).

Castañón, Laura Childhood Trauma Changes Your Brain. 2020. But it doesn't Have to be Permanent. News@Northeastern. Available online: https:/ / news.northeastern.edu/2020/02/20/childhood-trauma-changes-your-brain-but-it-doesnt-have-tobe-permanent/ (accessed on 12 October 2021).

Cobbe, Frances P. 1878. Wife torture in England. The Contemporary Review 32: 69.

Colich, Natalie L., Maya L. Rosen, Eileen S. Williams, and Katie A. McLaughlin. 2020. Biological aging in childhood and adolescence following experiences of threat and deprivation: A systematic review and meta-analysis. Psychological Bulletin 146: 721. [CrossRef] [PubMed]

Connors, Mary E. 1997. The Renunciation of Love: Dismissive Attachment and Its Treatment. Psychoanalytic Psychology 14: 475-93. [CrossRef]

Craddock, Gerald, Cormac Doran, and Larry McNutt, eds. 2018. Transforming Our World through Design, Diversity and Education: Proceedings of Universal Design and Higher Education in Transformation Congress. Amsterdam: IOS Press, vols. 256.

DePaulo, Bella. 2016. Psychologist Reveals Science Behind a Fulfilling Single Life. American Psychological Association. Available online: https: / / www.apa.org (accessed on 12 October 2021).

Duschinsky, Robbie. 2020. Cornerstones of Attachment Research. Oxford: Oxford University Press.

Edelstein, Robin S., and Phillip R. Shaver. 2004. Avoidant attachment: Exploration of an oxymoron. In Handbook of Closeness and Intimacy. Hove: Psychology Press, pp. 407-22.

Elsevier. 2021. Childhood Neglect Leaves Generational Imprint: Distinct Neural Connectivity Found in the Babies of Mothers Who Experienced Neglect as Children. ScienceDaily. Available online: www.sciencedaily.com/releases/2021/01/210119085222.htm (accessed on 12 October 2021).

Evans, Tanya. 2021. How Do Family Historians Work with Memory? Journal of Family History 46: 92-106. [CrossRef]

Fearon, Pasco. 2004. Comments on Turton Et Al: On the Complexities of Trauma, Loss and the Intergenerational Transmission of Disorganized Relationships. Attachment \& Human Development 6: 255-61. [CrossRef]

Feeney, Brooke C., Jude Cassidy, and Fatima Ramos-Marcuse. 2008. The Generalization of Attachment Representations to New Social Situations: Predicting Behavior during Initial Interactions with Strangers. Journal of Personality and Social Psychology 95: 1481-98. [CrossRef]

Felitti, Vincent J. 2002. The relationship of adverse childhood experiences to adult health: Turning gold into lead/Belastungen in der Kindheit und Gesundheit im Erwachsenenalter: Die Verwandlung von Gold in Blei. Zeitschrift für Psychosomatische Medizin und Psychotherapie 48: 359-69. [CrossRef] [PubMed]

Felitti, Vincent J., Robert F. Anda, Dale Nordenberg, David F. Williamson, Alison M. Spitz, Valerie Edwards, Mary P. Koss, and James S. Marks. 2019. Reprint of: Relationship of childhood abuse and household dysfunction to many of the leading causes of death in adults: The adverse childhood experiences (ACE) study. American Journal of Preventive Medicine 56: 774-86. [CrossRef] [PubMed]

Firestone, Lisa. 2013. How Your Attachment Style Affects Your Parenting. Psychology Today. Available online: https://www. psychologytoday.com/us/blog/compassion-matters/201510/how-your-attachment-style-affects-your-parenting (accessed on 12 October 2021).

Fraga, Juli. 2018. Learn Your Own Attachment Style to Become a Better Parent I Aeon Essays. Aeon. Available online: https: / / aeon.co/essays/learn-your-own-attachment-style-to-become-a-better-parent (accessed on 12 October 2021).

Fraley, R. Chris, and Phillip R. Shaver. 1997. Adult attachment and the suppression of unwanted thoughts. Journal of Personality and Social Psychology 73: 1080-91. [CrossRef]

Fraley, R. Chris, and Phillip R. Shaver. 2000. Adult romantic attachment: Theoretical developments, emerging controversies, and unanswered questions. Review of General Psychology 4: 132-54. [CrossRef]

Genetics and Epigenetics of Addiction Drugfacts I National Institute on Drug Abuse. 2019. National Institute on Drug Abuse. Available online: https:/ / www.drugabuse.gov/publications/drugfacts/genetics-epigenetics-addiction (accessed on 12 October 2021).

Gillies, James, and Robert A. Neimeyer. 2006. Loss, Grief, and the Search for Significance: Toward a Model of Meaning Reconstruction in Bereavement. Journal of Constructivist Psychology 19: 31-65. [CrossRef]

Griffin, Emma. 2020. Bread Winner: An Intimate History of the Victorian Economy. New Haven and London: Yale University Press.

Grossmann, Karin. 1989. Avoidance as a communicative strategy in attachment relationships. Paper presented at the Fourth World Congress for Infant Psychiatry and Allied Disciplines, Lugano, Switzerland, September 20-24. 
Hendrix, Cassandra L., Daniel D. Dilks, Brooke G. McKenna, Anne L. Dunlop, Elizabeth J. Corwin, and Patricia A. Brennan. 2021. Maternal Childhood Adversity Associates with Frontoamygdala Connectivity in Neonates. Biological Psychiatry: Cognitive Neuroscience and Neuroimaging 6: 470-78. [CrossRef]

Hinrichs, Jonathan, Jared DeFife, and Drew Westen. 2011. Personality Subtypes in Adolescent and Adult Children of Alcoholics. Journal of Nervous \& Mental Disease 199: 487-98. [CrossRef]

Hirsch, Marianne. 2008. The generation of postmemory. Poetics Today 29: 103-28. [CrossRef]

Huberman, Michael, and Chris Minns. 2007. The times they are not changin': Days and hours of work in Old and New Worlds, 1870-2000. Explorations in Economic History 44: 538-67. [CrossRef]

Iyengar, Udita, Purva Rajhans, Peter Fonagy, Lane Strathearn, and Sohye Kim. 2019. Unresolved Trauma and Reorganization in Mothers: Attachment and Neuroscience Perspectives. Frontiers in Psychology 10: 1-9. [CrossRef]

Jarrett, Christian. 2019. First Study to Investigate How Attachment Style Changes through Multiple Decades of Life. Research Digest. Available online: https:/ / digest.bps.org.uk/2019/05/09/first-study-to-investigate-how-attachment-style-changes-throughmultiple-decades-of-life/ (accessed on 12 October 2021).

Joinson, Carla. 2018. Prairie Madness | Healing, Hell, and the History of American Insane Asylums. Available online: https: //hhhasylum.com/tag/prairie-madness / (accessed on 12 October 2021).

Kelley, Michelle L., Valarie M. Schroeder, Cathy G. Cooke, Leslie Gumienny, Amanda Jeffrey Platter, and William Fals-Stewart. 2010. Mothers' Versus Fathers' Alcohol Abuse and Attachment in Adult Daughters of Alcoholics. Journal of Family Issues 31: 1555-70. [CrossRef]

Khodabakhsh, Mohammadreza. 2012. Attachment styles as predictors of empathy in nursing students. Journal of Medical Ethics and History of Medicine 5: 1-7.

Kim, Sohye, Peter Fonagy, Jon Allen, and Lane Strathearn. 2014. Mothers' Unresolved Trauma Blunts Amygdala Response to Infant Distress. Social Neuroscience 9: 352-63. [CrossRef]

Kirmayer, Laurence J., Gregory M. Brass, and Caroline L. Tait. 2000. The mental health of Aboriginal peoples: Transformations of identity and community. The Canadian Journal of Psychiatry 45: 607-16. [CrossRef]

Kokou-Kpolou, Cyrille Kossigan, Sunyoung Park, Lonneke IM Lenferink, Steven Kotar Iorfa, Manuel Fernández-Alcántara, Daniel Derivois, and Jude Mary Cénat. 2021. Prolonged grief and depression: A latent class analysis. Psychiatry Research 299: 113864. [CrossRef] [PubMed]

Lai, Carlo, Massimiliano Luciani, Federico Galli, Emanuela Morelli, Roberta Cappelluti, Italo Penco, Paola Aceto, and Luigi Lombardo. 2015. Attachment style dimensions can affect prolonged grief risk in caregivers of terminally ill patients with cancer. American Journal of Hospice and Palliative Medicine 32: 855-60. [CrossRef]

Landsberg, Alison. 2009. Memory, empathy, and the politics of identification. International Journal of Politics, Culture, and Society 22: 221-9. [CrossRef]

Langhamer, Claire. 2013. The English in Love: The Intimate Story of an Emotional Revolution, 1st ed. Oxford: Oxford University Press.

Lanzoni, Susan. 2015. A Short History of Empathy. The Atlantic. Available online: https://www.theatlantic.com/health/archive/2015 /10/a-short-history-of-empathy/409912/ (accessed on 12 October 2021).

Lapping, Claudia. 2019. Mourning and Melancholia. In The Routledge Handbook of Psychoanalytic Political Theory. Edited by Yannis Stavrakakis. London and New York: Routledge, pp. 208-20.

Lovett, Joan. 2014. Trauma-Attachment Tangle: Modifying Emdr to Help Children Resolve Trauma and Develop Loving Relationships. New York and London: Routledge.

Lupien, Sonia J., Sophie Parent, Alan C. Evans, Richard E. Tremblay, Philip David Zelazo, Vincent Corbo, Jens C. Pruessner, and Jean R. Séguin. 2011. Larger amygdala but no change in hippocampal volume in 10-year-old children exposed to maternal depressive symptomatology since birth. Proceedings of the National Academy of Sciences 108: 14324-9. [CrossRef]

Maccallum, Fiona, and Richard A. Bryant. 2018. Prolonged Grief and Attachment Security: A Latent Class Analysis. Psychiatry Research 268: 297-302. [CrossRef]

McEwen, Bruce S., and Huda Akil. 2020. Revisiting the stress concept: Implications for affective disorders. Journal of Neuroscience 40: 12-21. [CrossRef]

McIntosh, Tania. 1997. A Price Must Be Paid for Motherhood: The Experience of Maternity in Sheffield, 1879-1939. Ph.D. dissertation, University of Sheffield, Sheffield, UK.

Mikulincer, Mario, and Victor Florian. 1998. The relationship between adult attachment styles and emotional and cognitive reactions to stressful events. In Attachment Theory and Close Relationships. Edited by Jeffry A. Simpson and William SE. Rholes. New York: Guilford Press, pp. 143-65.

Mikulincer, Mario, and Phillip R. Shaver. 2003. The attachment behavioral system in adulthood: Activation, psychodynamics, and interpersonal processes. In Advances in Experimental Social Psychology. Edited by Mark P. Zanna. San Diego: Academic Press, vols. 35, pp. 53-152.

Moore, Susan, Doreen Rosenthal, and Rebecca Robinson. 2020. The Psychology of Family History: Exploring Our Genealogy. London and New York: Routledge. 
Nickerson, Angela, Richard A. Bryant, Idan M. Aderka, Devon E. Hinton, and Stefan G. Hofmann. 2013. The impacts of parental loss and adverse parenting on mental health: Findings from the National Comorbidity Survey-Replication. Psychological Trauma: Theory, Research, Practice, and Policy 5: 119-27. [CrossRef]

Parker-Drabble, Helen. 2020. Who Do I Think You Were? A Victorian's Inheritance. London: Animi Press.

Prescott, Carol A., Steven H. Aggen, and Kenneth S. Kendler. 2000. Sex-specific genetic influences on the comorbidity of alcoholism and major depression in a population-based sample of US twins. Archives of General Psychiatry 57: 803-11. [CrossRef] [PubMed]

Qin, Shaozheng, Christina B. Young, Xujun Duan, Tianwen Chen, Kaustubh Supekar, and Vinod Menon. 2014. Amygdala Subregional Structure and Intrinsic Functional Connectivity Predicts Individual Differences in Anxiety During Early Childhood. Biological Psychiatry 75: 892-900. [CrossRef] [PubMed]

Reisz, Samantha, Robbie Duschinsky, and Daniel J. Siegel. 2018. Disorganized attachment and defense: Exploring John Bowlby's unpublished reflections. Attachment E Human Development 20: 107-34. [CrossRef]

Risks to Mental Health: An Overview of Vulnerabilities and Risk Factors-Background Paper by WHO Secretariat for the Development of a Comprehensive Mental Health Action Plan. 2012. Geneva: World Health Organization, Available online: https://www.who.int/ mental_health/mhgap/risks_to_mental_health_EN_27_08_12.pdf (accessed on 12 October 2021).

Rollero, Chiara, and Norma De Piccoli. 2010. Place attachment, identification and environment perception: An empirical study. Journal of Environmental Psychology 30: 198-205. [CrossRef]

Saatcioglu, Omer, Rahsan Erim, and Durcan Cakmak. 2006. Role of Family in Alcohol and Substance Abuse. Psychiatry and Clinical Neurosciences 60: 125-32. [CrossRef]

Saphire-Bernstein, Shimon, Baldwin. M. Way, Heejung S. Kim, David K. Sherman, and Shelley E. Taylor. 2011. Oxytocin Receptor Gene (OXTR) Is Related to Psychological Resources. Proceedings of the National Academy of Sciences 108: 15118-22. [CrossRef]

Schindler, Andreas. 2019. Attachment and substance use disorders-theoretical models, empirical evidence, and implications for treatment. Frontiers in Psychiatry 10: 727. [CrossRef] [PubMed]

Schumann, Karina, and Edward Orehek. 2017. Avoidant and Defensive: Adult Attachment and Quality of Apologies. Journal of Social and Personal Relationships 36: 809-33. [CrossRef]

Seymour, Susan. 2013. It Takes a Village to Raise a Child: Attachment Theory and Multiple Childcare in Alor, Indonesia, and in North India. In Attachment Reconsidered: Cultural Perspectives on A Western Theory. New York: Palgrave Macmillan, pp. 115-39.

Shaver, Phillip R., and Cindy Hazan. 1993. Adult romantic attachment: Theory and evidence. In Advances in Personal Relationships. Edited by Daniel Perlman and Warren Jones. London: Jessica Kingsley, vols. 4, pp. 29-70.

Shaw, Emma. 2020. “Who We Are, And Why We Do It": A Demographic Overview and The Cited Motivations of Australia's Family Historians. Journal of Family History 45: 109-24. [CrossRef]

Simpson, Jeffry A., and Jay Belsky. 2008. Attachment Theory within a Modern Evolutionary Framework: Theory, Research, and Clinical Applications. In Handbook of Attachment: Theory, Research, And Clinical Applications. Edited by Jude Cassidy and Phillip R. Shaver. New York: Guilford, pp. 91-116.

Solomon, Andrew. 2001. The Noonday Demon: An Atlas of Depression. New York: Scribner.

Sochos, Antigonos, and Sadia Aleem. 2021. Parental Attachment Style and Young Persons' Adjustment to Bereavement. In Child E Youth Care Forum. New York and Philadelphia: Springer US, pp. 1-19.

Sotero, Michelle. 2006. A Conceptual Model of Historical Trauma: Implications for Public Health Practice and Research. Journal of Health Disparities Research and Practice 1: 93-108.

Strange, Julie-Marie. 2006. Dangerous Motherhood: Insanity and Childbirth in Victorian Britain by Hilary Marland. History $91: 471$. [CrossRef]

Strange, Julie-Marie. 2012. Fatherhood, Providing, And Attachment in Late Victorian and Edwardian Working-Class Families. The Historical Journal 55: 1007-27. [CrossRef]

Taggart, Geoff, and Jo Elsey. 2021. Supervision and Adult Attachment. Available online: https://tactyc.org.uk/pdfs/Taggart\%20and\% 20Elsey.pdf (accessed on 12 October 2021).

The Evacuated Children of the Second World War. 2021. Imperial War Museums. Available online: https://www.iwm.org.uk/history/ the-evacuated-children-of-the-second-world-war (accessed on 12 October 2021).

Thompson, Gavin, Oliver Hawkins, Aliyah Dar, and Mark Taylor. 2012. Olympic Britain: Social and economic change since the 1908 and 1948 London Games. Retrieved October 1: 2014.

Turan, Numan, William T. Hoyt, and Özgür Erdur-Baker. 2016. Gender, attachment orientations, rumination, and symptomatic distress: Test of a moderated mediation model. Personality and Individual Differences 102: 234-9. [CrossRef]

Turner, Sarah, Natalie Mota, James Bolton, and Jitender Sareen. 2018. Self-medication with alcohol or drugs for mood and anxiety disorders: A narrative review of the epidemiological literature. Depression and Anxiety 35: 851-60. [CrossRef]

Vaillant, George E. 2009. Natural History of Alcoholism, 2nd ed. Revisited. Cambridge: Harvard University Press.

Voges, Juané, Astrid Berg, and Dana J. H. Niehaus. 2019. Revisiting the African Origins of Attachment Research—50 Years on From Ainsworth: A Descriptive Review. Infant Mental Health Journal 40: 799-816. [CrossRef]

Vungkhanching, Martha, Kenneth J. Sher, Kristina M. Jackson, and Gilbert R. Parra. 2004. Relation of Attachment Style to Family History of Alcoholism and Alcohol Use Disorders in Early Adulthood. Drug and Alcohol Dependence 75: 47-53. [CrossRef]

Wegscheider, Sharon. 1981. Another Chance: Hope and Health for the Alcoholic Family, 1st ed. Palo Alto: Science and Behavior Books. 
West, Malcolm L., and Adrienne E. R. Keller. 1991. Parentification of the child: A case study of Bowlby's compulsive care-giving attachment pattern. American Journal of Psychotherapy 45: 425-31. [CrossRef]

Womersley, Kate, Katherine Ripullone, and Jane Elizabeth Hirst. 2021. Tackling inequality in maternal health: Beyond the postpartum. Future Healthcare Journal 8: 31. [CrossRef] [PubMed]

Yehuda, Rachel, and Amy Lehrner. 2018. Intergenerational Transmission of Trauma Effects: Putative Role of Epigenetic Mechanisms. World Psychiatry 17: 243-57. [CrossRef]

Zelekha, Yaron, and Erez Yaakobi. 2020. Intergenerational Attachment Orientations: Gender Differences and Environmental Contribution. PLoS ONE 15: e0233906. [CrossRef] 